\title{
Exploring the Relationship between Experiential Value and Usage Attitude towards Mobile Apps among the Smartphone Users
}

\author{
Farshad Maghnati ${ }^{1} \&$ Kwek Choon Ling ${ }^{1}$ \\ ${ }^{1}$ Faculty of Business and Information Technology (Science), UCSI University, Kuala Lumpur, Malaysia \\ Correspondence: Kwek Choon Ling, Faculty of Business and Information Technology (Science), UCSI \\ University. No. 1, Jalan Menara Gading, UCSI Heights, 56000 Kuala Lumpur, Malaysia. Tel: 60-16-688-6248. \\ E-mail:kwekcl@ucsi.edu.my
}

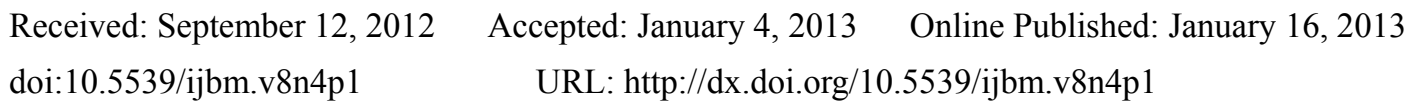

\begin{abstract}
The rapid growth of smartphone industry motivates companies to emphasize more on the elements of customers' experiential value in the process of promoting their products and services. The objective of this research is to evaluate the impacts of experiential value on the usage attitude towards the mobile apps among the smartphone users. The survey research was conducted among the tertiary students in which most of them are heavy users of mobile apps via the smartphones. A total of 550 sets of questionnaire were distributed in the survey and judgemental sampling technique was adopted in this research. The research confirmed that both customer return on investment (CROI) and playfulness have positive relationship with the usage attitude.
\end{abstract}

Keywords: experiential value, aesthetic, playfulness, service excellence, customer return on investment (CROI), usage attitude

\section{Introduction}

Mobile phone technology has changed rapidly since the advent of smartphone almost a decade ago (Paterson and Low, 2011). According to the statistics from Euromonitor International (2011), the value of mobile phones has grown around $14 \%$ and recorded RM2.6 billion in sale for 2010. Smart phone industry has experienced higher value growth of $29 \%$ as comparing to the feature phones. Demand of smart phones has been increased due to its functions and popularity such as performing instant messaging, downloading mobile apps, connecting to the Wi-Fi and viewing entertainment programme (Park and Chen, 2007; Euromonitor, 2011). Based on the statistical report presented by IT sideways (adopted from http://www.it-sideways.com/, retrieved on 1st of June 2012), approximately $41 \%$ and $38 \%$ of the smart phone owners is within the age group of $25-34$ year olds and $18-24$ year olds respectively. With the proliferation of the mobile apps used in the smartphones that targeting the young consumers group, the experience value is becoming one of the critical success factors in influencing the usage attitude towards the mobile apps among the smartphone users. Therefore, this study would like to explore the concept of experiential value and its influence on the usage attitude towards the mobile apps among the smartphone users in Malaysia.

\section{Literature Review}

\subsection{Usage Attitude}

The concept of attitude is one of the most important issues being discussed in the field of consumer behaviour. Birgelen et al. (2003) defined attitude as "a psychological tendency that is expressed by evaluating a particular entity with some degree of favour or disfavour". Malhotra (2005) defined attitude as a summary of appraisal of an object, and stated that beliefs is very important in person attitude because of its stability in mind, people have different beliefs in different objects and usually their beliefs lead them to the objects and change their attitude which can form positive or negative reaction. Maio and Haddock (2010) argued that both negative and positive reactions in the psychological science can be reflected in attitude. In fact, attitudes have demonstrated their efficacies as a predictor's of behaviours and behavioural intentions in a variety of contexts including work related behaviours (Morris et al., 2009). In addition, attitude can be directly related to the environmental responsiveness because Maio and Haddock (2010) suggested that by holding to their attitude, people are able to determine the approaches in responding to their environment. By responding to a service or a brand, people form their attitude 
measurement based on what they believe and how they feel about the service or a brand (Farris et al., 2003).

Solomon et al. (2006) classified attitude into three different components: affect, behaviour and cognition. Affect is described by Solomon et al. (2006) as the way of customer feeling toward a particular attitude object and the process is instinctive and less likely to be affected by availability of processing resources (Malhotra, 2005). Whereas, behaviour involves the customer intention to do something to an attitude object (Solomon et al., 2006). Lastly, cognition can be referred to the beliefs that a customer has about an attitude object (Solomon et al., 2006). Malhotra (2005) argued that people are able to control cognition process and it is obviously that this process will be affected by the availability of processing resources. Cognition and affect process are in opposite of each other in which means that if processing resources are low, then customers are more likely to use affective responses but if processing resources are high, people prefer to use cognitive reaction. According to Hassan et al. (2011), both belief and attitude can influence on individual usage behaviour. Based on Keng et al. (2007), experiential value has positive effect on usage attitude. A separate study carried out by Keng and Ting (2009) also indicated that experiential value has a positive impact on usage attitude. The dimensions of experiential value tested by Keng and Ting (2009) include aesthetic, service excellence and playfulness.

In addition, Nambisan and Baron (2007) also asserted that the user perception and attitude in certain extant are influenced by the experiential values which are generated from the inner personal. Therefore, the following content will elaborate the concept of experiential value and its impacts on usage attitude.

\subsection{Experiential Value}

In the past, the value that stimulates utilization behaviour has been related to functional, conditional, social, emotional and epistemic utility (Sheth, Newman and Gross, 1991). In spite of this broad conceptualization, empirical researchers have conventionally take value more closely as the exchange between quality and price (Dodds and Monroe, 1985; Yadav and Monroe, 1993). However, these early viewpoints of customer value mostly neglected the hedonic and experiential of use (Sweeney and Sountar, 2001). Furthermore, the utilization experience itself can also be rich in value. According to Mathwick, Malhotra and Rigdon (2001), retailers are starting to place themselves as providers of memories and experiences rather than products and services, and convert the retailing environment as an interactive theatres rather than being as sales outlets.

Lee and Overby (2004) argued that value is subjective and it is resulting of exchange of experience by customers or individual perception which it is not simply a utilitarian value. In other words, experiential value perceptions usually depend upon interactions involving direct usage or distanced admiration of goods and services. These interfaces offer the foundation for the relativistic preferences held by the individuals involved (Holbrook and Corfman, 1985). Therefore, Wu and Liang (2009) defined experiential value as consumer assessments of service efficiency, service excellence, aesthetic, and playfulness in the service encounter. Schroeder (2012) mentioned that the real experience can be faded but forgetting the experiential value will be harder. Holbrook (2000) argued that consumption experiences play important roles in the customer decision making. Gentile et al. (2007) also hold the similar conclusion and asserted that the product and experiential values can be created via consuming experience. Mathwick et al. (2001) asserted that customer value is typically built on the experiential perception and it is the result of the indirect or direct contact during the consumption process.

In the experiential marketing literature, a few scholars had tried to find the value that consumers benefit from consuming an experiential offer (Holbrook and Hirschman, 1982; Holbrook, 1994; Mathwick et al., 2001). Accordingly to Holbrook (1994), experiential values can be divided into two dimensions: instrinsic vs. extrinsic and active vs. reactive. Extrinsic values mainly focus on the utilitarian benefits of shopping; intrinsic values point to the admiration of an experience for its own sake, apart from any other outcomes that may result (Holbrook, 1994). Reactive or passive values can be referred to the level to which a consumer understands, appreciates, or reacts to a consumption item or experience. Active or participative values, in contrast, are formed when there is an increased level of alliance between the customer and the product/service providers. Building on the work of Holbrook (1994), Mathwick et al. (2001) had developed a typology of experiential values that including the values of playfulness, aesthetics, service excellence, and customer return on investment. The following session will elaborate the four dimensions of customer experiential value which are proposed by Mathwick et al. (2001) in detail.

\subsubsection{Aesthetic}

Aesthetic is the value created from the joint dimension between intrinsic value and reactive value (Mathwick et al., 2001). Veryzer (1993) described the aesthetic value as a reaction to the unity of a physical object or performance. Aesthetic is known by visual appeal and entertainment (Holbrook, 2000). Mathwick et al. (2001) argued that there 
are two major features of aesthetic: (1) experience perceived through the primary senses such as sight, hearing, taste and touch that offer satisfaction to the customers; and (2) experience perceived through dramatic affect or entertainment. Both visual appearance and the entertainment dimension of the aesthetic response do deliver instant pleasure for its own sake, irrespective whether the physical environment able to accomplish the tasks carried out by the consumers (Deighton and Grayson, 1995; Driefus, 1997).

\subsubsection{Playfulness}

Playfulness is the value created from the joint dimension between intrinsic value and active value (Mathwick et al., 2001). The value of playfulness is generated by customers and it is completely inner, initiative and self-oriented experience (Chou, 2009). The playful value mirrors emotional worth and potential amusement of the shopping process (Mathwick et al., 2001). In other words, playful exchange behaviour is reproduced in the inner enjoyment that generated from the engagement in activities that are fascinating, to the point of an escape from the demands of world (Day, 1981). Thus, Chou (2009) concluded that playfulness is a pleasure or enjoyment which is derived by individual assessing of a product or service.

\subsubsection{Service Excellence}

Service excellent is the value created from the joint dimension between extrinsic value and reactive value (Mathwick et al., 2001). According to Chou (2009), service excellence is a customer experience that provides self-oriented, reactive value and extrinsic. The value of service excellent is expressed in term of consumer thankfulness towards a service provider who has established expertise and offers a reliable service performance (Holbrook, 2000). From the perspective of customer's service excellence, service excellence is part of the reaction side of the customer experience (Veryzer, 1993).

\subsubsection{Consumer Return on Investment (CROI)}

CROI is the value created from the joint dimension between extrinsic value and active value (Mathwick et al., 2001). In general, the CROI explains what consumer receives in return in the exchange process. The customer might experience this return on investment in terms of economic benefit that is the perception of affordable quality (Thaler, 1985; Grewel, Monroe and Krishnan, 1996; Yadov and Monroe, 1993) as well as utility obtained from the competence of an exchange encounter (Holbrook, 1994; Zeithaml, 1988). Therefore, CROI value reflects the effective aspect of activities engagement, and explains active investment in economic, psychological resources, behavioural, and emotions that yield rewards (Holbrook, 2000; Mathwick et al., 2001).

\subsection{Research Gap and Justification}

Customer experiential value is a very dynamic construct and it is subjected to change due to the advancement of the mobile apps used in the smartphone products. Although Keng and Ting (2009) had conducted the relationship study between the experiential value and usage attitude, the similar study of the conceptual framework in the context of evaluating the impact of experiential value on the usage attitude towards the mobile apps among the smartphone users in Malaysia is still not yet available. By undergoing this study, the findings may provide a clear view what are the current customer experiential values towards the usage attitude of mobile apps among the smartphone users (primarily the young customer groups) as well as how to embed the customer experiential values in designing new mobile apps.

\subsection{Proposed Conceptual Model}

The conceptual framework for this research was adapted from the Keng and Ting model (2009). Figure 1 illustrates the conceptual framework which is developed for this research.

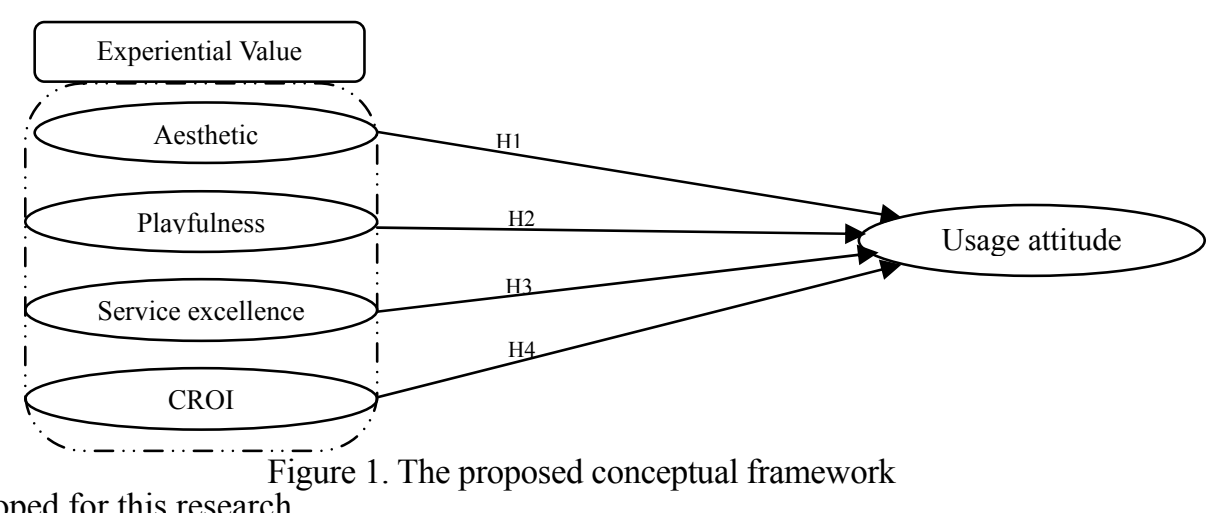

Source: Developed for this research 


\subsection{Hypotheses}

Prior discussion has led to a brief examination of the existing literature review and the development of the hypotheses in this research. The four tested hypotheses are:

H1: Aesthetic is positively related to the usage attitude

H2: Playfulness is positively related to the usage attitude

H3: Service Excellence is positively related to the usage attitude

H4: Customer Return on Investment (CROI) is positively related to the usage attitude

\section{Research Methodology}

\subsection{Research Design}

Positivism approach in term of descriptive research will be adopted in this research to study the relationship between the experiential value and usage attitude because the research has clear body of knowledge and specific hypotheses (Malhotra, 2004). Quantitative study will be carried out for this study for the purpose of summarizing and generalizing the hypotheses tested that derived from the theory. Primary data will be collected via cross-sectional study in this study because of the need to study current usage attitudes among the young consumer groups who are using mobile apps via the smartphones.

\subsection{Questionnaire Design}

The questionnaire was divided into two (2) sections, namely Sections A and B. The variables that appear in the Section A include the demographic profiles, such as gender, age, and highest academic qualification level. All the variables that measure the tested constructs were listed in Section B of the questionnaire. A total of 2 items that measure the constructs 'service excellence' and 'aesthetic' respectively were adapted from Keng et al. (2007). Another 3 items that measure the constructs 'customer return on investment' and 'playfulness' respectively were adapted from Keng et al. (2007). The 'usage attitude' would be measured by 3 items and the items were adapted from Keng and Ting (2009). All the tested constructs were measured by 5-point Likert Scale (1-strongly disagree to 5- strongly agree).

\subsection{Sampling Design}

The study will focus on the full time students who are currently studying in one of the private universities that allocated in Kuala Lumpur. Tertiary students were selected in this study because most of them own smart phones and their age groups are similar to the age group of the smart phone users in the country. Due to the inability of compiling a sampling frame, non-probability sampling was adopted in this research. Judgmental sampling technique was adopted as non-probability sampling because the technique itself allows the researchers to consciously select respondents in the study (Burn and Bush, 2003). Large sample size was required in this research for the purpose of minimizing the sampling error of the non-probability sampling and enhancing the precision of the sampling outcome. Therefore, a total of 550 respondents were set as the sample size in this research.

A pilot study was conducted in advance to ensure that the questionnaire is error free and easy to understand. A full scale of self-administered survey was launched immediate after receiving the feedbacks from the pilot test. Self-administered survey method in the form of drop-off surveys technique was used to ensure the confidentiality and non-obligation aspects of participating in the survey. The survey was conducted in the lecture halls where respondents could return the questionnaires immediately to the researchers. The voluntary nature of the participation was explained verbally as well as being indicated in the survey questionnaire. Students were invited to complete an anonymous survey questionnaire that took approximately 15 minutes of their time to complete. A total of 550 sets of questionnaires were distributed and 500 questionnaires were collected.

\subsection{Data Analysis}

The statistical Program SPSS version 20.0 would be used in this study to perform the statistical analysis. Descriptive analysis, scale measurement (reliability and validity tests) and inferential analysis (multiple regression analysis) would be carried out in the data analysis.

\section{Research Results}

\subsection{Respondents' Demographic Profiles Analysis}

According to the 500 valid collected questionnaires from the survey, the results indicated that $42 \%$ of the respondents were male and $58 \%$ were female. In term of the age group, the age group of less than 21 years old 
(46\%) and age group between 21-25 years old (45.8\%) were the two major age groups of respondents in the study. The results also revealed that most of the respondents $(61.4 \%)$ are currently pursuing their undergraduate degree programme.

\subsection{Reliability Test}

Reliability is referred to the degree in which the scale measurements are free from errors and yields consistent result from the study (Bajpai, 2011). According to Bernard (2000), there are three types of reliability: stability reliability, representative reliability and equivalence reliability. Cronbach's alpha was used in this research to evaluate the reliability of the scale measurement. The value of Cronbach's alpha greater than 0.60 was used as a guideline to evaluate the reliability test (Hair et al., 2006). The results from Table 1 indicated that the Cronbach alpha for all the five constructs were well above 0.60 as recommended by Hair et al. (2003). Cronbach alpha for the constructs ranged from the lowest of 0.667 (usage attitude) to 0.802 (aesthetic), as indicated in Table 1. In conclusion, the result concluded that the measurement scales of the constructs were stable in measuring the constructs.

\subsection{Validity Test}

Validity measurement was defined as the ability of a scale to measure what was intended to be measured. There are three types of measurement validity: content validity, criterion validity, constructs validity (Cavana et al., 2001). Construct validity was adopted in this research as validity measurement and exploratory factor analysis was used to measure the construct validity (Cavana et al., 2001). The output of the factor analysis showed in Table 1 indicated that the factor analysis was proper because the value of Kaiser-Meyer-Olkin (KMO) was 0.664 (between 0.5 and 1.0) and the statistical test for Bartlett test of sphericity was significant $(\mathrm{p}=0.000 ; \mathrm{df}=78$; approx. Chi-Square=1718.816) for all the correlations within a correlational matrix (at least for some of the constructs). Based on the principal components analysis and VARIMAX procedure in orthogonal rotation that were adopted in the factor analysis, the results showed that the Eigenvalues for all the tested constructs were greater than 1.0 as indicated in Table 1, ranging from the lowest of 1.111 (service excellence) to the highest of 3.276 (playfulness). In term of convergent validity, the factor loadings for all items within the constructs showed in Table 1 were more than 0.50 . According to Table 1 , discriminant validity indicated that all items were allocated according to the different constructs. Therefore, the items were not overlapping and they supported respective constructs.

Table 1. Factors identified by the principal components factor analysis

\begin{tabular}{|c|c|c|c|c|c|}
\hline $\begin{array}{l}\text { Factor's } \\
\text { Name }\end{array}$ & Variable & $\begin{array}{l}\text { Factor } \\
\text { Loading }\end{array}$ & $\begin{array}{l}\text { Eigen- } \\
\text { value }\end{array}$ & $\begin{array}{c}\text { Percentage } \\
\text { of Variance } \\
\text { Explained }\end{array}$ & $\begin{array}{l}\text { Cronbach's } \\
\text { Reliability } \\
\text { Coefficients }\end{array}$ \\
\hline \multirow[t]{3}{*}{ Playfulness } & $\begin{array}{l}\text { Using of mobile apps on smartphones makes me } \\
\text { cheerful }\end{array}$ & 0.826 & 3.276 & 15.503 & 0.738 \\
\hline & $\begin{array}{l}\text { I feel happy when I use mobile apps on } \\
\text { smartphones }\end{array}$ & 0.812 & & & \\
\hline & $\begin{array}{l}\text { Using of mobile apps on smartphones makes me } \\
\text { forget my problem encountered }\end{array}$ & 0.760 & & & \\
\hline \multirow{3}{*}{$\begin{array}{l}\text { Customer } \\
\text { return on } \\
\text { investment } \\
(\mathrm{CROI})\end{array}$} & $\begin{array}{l}\text { Using of mobile apps on smartphones makes my } \\
\text { life easier }\end{array}$ & 0.802 & 1.712 & 14.823 & 0.719 \\
\hline & $\begin{array}{l}\text { Using of mobile apps on smartphones fits my plan } \\
\text { schedule }\end{array}$ & 0.755 & & & \\
\hline & $\begin{array}{l}\text { The feature assortment of the mobile apps that } \\
\text { embedded in the smartphones fits my needs }\end{array}$ & 0.750 & & & \\
\hline \multirow[t]{2}{*}{ Aesthetic } & $\begin{array}{l}\text { The mobile apps on smartphones are aesthetically } \\
\text { appealing }\end{array}$ & 0.908 & 1.400 & 12.924 & 0.802 \\
\hline & I like the design of the mobile apps on smartphones & 0.914 & & & \\
\hline \multirow[t]{2}{*}{$\begin{array}{l}\text { Service } \\
\text { excellence }\end{array}$} & $\begin{array}{l}\text { When I think of mobile apps on smartphones, I } \\
\text { think of service excellence }\end{array}$ & 0.883 & 1.111 & 12.110 & 0.702 \\
\hline & $\begin{array}{l}\text { I think of particular mobile apps on smartphone } \\
\text { brand as an expert in the merchandise it offer }\end{array}$ & 0.853 & & & \\
\hline
\end{tabular}




\begin{tabular}{llllll}
\hline Usage & I enjoy being the owner of the mobile apps on & 0.785 & 1.546 & 14.217 & 0.667 \\
attitude & smartphones \\
& $\begin{array}{l}\text { The benefits that gained from using the mobile } \\
\text { apps on smartphone outweigh the cost of owning }\end{array}$ & 0.728 & & \\
mobile apps on smartphone & & & \\
The mobile apps on smartphone is something I & 0.746 & & \\
look upon favourably &
\end{tabular}

Note: KMO Measures of Sampling Adequacy $=0.664 ; \mathrm{p}=0.000(\mathrm{p}<0.05) ; \mathrm{df}=78 ;$ Approx. Chi-Square $=$ 1718.816

Source: Develop for this research

\subsection{Regression Analysis}

\subsubsection{Multiple Regression Analysis}

According to Cohen et al. (2003), multiple regression analysis is a statistical method which analyses the linear relationship between independent variables and dependent variable and multiplied by estimating coefficients for the equation of a straight line. Multiple regression analysis will be carried out to test the four hypotheses (H1, $\mathrm{H} 2, \mathrm{H} 3$, and $\mathrm{H} 4)$ in this research.

Based on Table 2, the Tolerance Value was ranged between 0.882-0.992 in which were all more than 0.10 and the VIF value ranges from 1.008-1.133 in which are all less than 5 (Hair et al., 2006). The findings showed that there is no multicollinearity problem among all the independent variables in this research. According to Table 2, the p-value for two out of four independent variables are less than 0.05 , indicating that only playfulness and customer return on investment (CROI) have significant positive relationship with usage attitude.

Table 2. Result of multiple linear regression analysis

\begin{tabular}{|c|c|c|c|c|c|c|c|c|}
\hline \multicolumn{9}{|c|}{ Coefficients $^{\mathrm{a}}$} \\
\hline \multirow{2}{*}{\multicolumn{2}{|c|}{ Model }} & \multicolumn{2}{|c|}{$\begin{array}{l}\text { Unstandardized } \\
\text { Coefficients }\end{array}$} & \multirow{2}{*}{$\begin{array}{c}\begin{array}{c}\text { Standardized } \\
\text { Coefficients }\end{array} \\
\text { Beta }\end{array}$} & \multirow[t]{2}{*}{$\mathrm{t}$} & \multirow[t]{2}{*}{ Sig. } & \multicolumn{2}{|c|}{$\begin{array}{l}\text { Collinearity } \\
\text { Statistics }\end{array}$} \\
\hline & & B & Std. Error & & & & Tolerance & VIF \\
\hline \multirow{5}{*}{1} & (Constant) & 6.947 & .539 & & 12.885 & .000 & & \\
\hline & aesthetic & -.010 & .033 & -.013 & -.311 & .756 & .992 & 1.008 \\
\hline & playfulness & .158 & .031 & .218 & 5.158 & .000 & .923 & 1.084 \\
\hline & CROI & .278 & .038 & .318 & 7.352 & .000 & .882 & 1.133 \\
\hline & Service excellence & -.003 & .038 & -.004 & -.087 & .930 & .950 & 1.052 \\
\hline
\end{tabular}

a. Dependent Variable: Usage Attitude

b. Independent variables: aesthetic, playfulness, CROI (customer return on investment), and service excellence

Source: Develop for this research

\section{Conclusion}

\subsection{Conclusion of Hypotheses}

In conclusion, the result shows that customer return on investment (CROI) and playfulness have positive relationship with the usage attitude towards the mobile apps in the smartphone industry but aesthetic and service excellence do not have significant positive relationship with usage attitude towards the mobile apps because majority of the student respondents pay more attention in evaluating the return of investment and the degree of playfulness while in the process of using mobile apps through the smartphones. In addition, most of the mobile apps can be functioned by itself without further services required and students search for more utility functions that derived from the usage of the mobile apps via the smartphones. Thus, the values of aesthetic and service excellence may not be acting as significant factors in influencing the usage of mobile apps via the smartphones among the tertiary students. 


\subsection{Implications of Research Findings}

This study helps the smartphone and mobile apps industries to gain further understanding the impacts of CROI and playfulness on the usage attitude towards the mobile apps among the smartphone users. The research study provides clues to the mobile apps developers and smartphone producers to have an in-depth understanding how the experiential value contributes to the usage attitude towards mobile apps among the smartphone users.

\subsection{Limitations of the Research}

There are some limitations in this research: (1) This study was adopting judgemental sampling technique method. Thus, the result could not be generalized; (2) This study was conducted via cross sectional study. Thus, the changes of the customers' usage attitude over a period of time can not be identified.

\subsection{Recommendations for the Future Research}

For the purpose of overcoming the above limitations in the research, it is recommended to adopt probability sampling method and longitudinal study for the future research.

\section{References}

Bajpai, N. (2011). Business research methods. India: Pearson Education.

Bernard, H. R. (2000). Social research methods: Qualitative and quantitative approaches. SAGE Publication Inc.

Birgelen, M. V., Ruyter, K. D., \& Wetzels, M. (2003). The impact of attitude strength on customer-oriented priority setting by decision-makers: An empirical investigation. Journal of Economic Psychology, 24(6), 763-783. http://dx.doi.org/10.1016/S0167-4870(03)00052-7

Burns, A., \& Bush, R. (2003). Marketing research: Online research application. New Jersey: Prentice Hall.

Cavana, R. Y., Delahaye, B. L., \& Sekaran, U. (2001). Applied business research: Qualitative and quantitative methods. Queensland: John Wiley \& Sons.

Chou, H. J. (2009). The effect of experiential and relationship marketing on customer value: A case study of international American casual dining chains in Taiwan. Social Behavior and Personality, 37(7), 998.

Cohen, J., Cohen, P., West, S. G., \& Aiken, L. S. (2003). Applied multiple regression/correlation analysis for the behavioral sciences (3rd ed.). Hillsdale, NJ: Erlbaum.

Day, G. S. (1981). The product life cycle: Analysis and applications issues. Journal of Marketing, 45(4), 60-67. http://dx.doi.org/10.2307/1251472

Deighton, J., \& Grayson, K. (1995). Marketing and seduction: Building exchange relationships by managing social consensus. Journal of Consumer Research, 21(March), 660-676. http://dx.doi.org/10.1086/209426

Dodds, W. B., \& Monroe, K. B. (1985). The effect of brand and price information on subjective product evaluations. Advances in Consumer Research, 12, 87-90.

Driefus, C. (1997). Talking shop. A conversation with the men who brought you Neiman Marcus, Ikea and Virgin. The New York Times Magazine, 6, 82-86.

Farris, W. P., Bendle, N. T., Pfeifer, P. E., \& Reibstein, D. J. (2003). Marketing metrics: Understanding market share and related metrics. Pearson Prentice Hall.

Gentile, C., Spiller, N., \& Noci, G. (2007). How to sustain the customer experience: An overview of experience components that co-create value with the Customer. European Management Journal, 25(5), 395-410. http://dx.doi.org/10.1016/j.emj.2007.08.005

Grewal, D., Monroe, K. B., \& Krishnan, R. (1996). The effects of price-comparison advertising on buyers' perceptions of acquisition value and transaction value. Marketing Science Institute, Report No. 96-103, May, Cambridge, MA.

Hair, J. F. J., Black, W. C., Babin, B. J., Anderson, R. E., \& Tatham, R. L. (2006). Multivariate data analysis. New Jersey: Pearson Education.

Hair, J. F. Jr., Babin, B., Money, A. H., \& Samouel, P. (2003). Essential of business research methods. John United States of America: Wiley \& Sons.

Hassan, M. A., Samah, B. A., Shaffril, H. A. M., \& D’Silva, J. L. (2011). Socio-demographic factors affecting attitude towards information and communication technology usage. American Journal of Applied Sciences, 8(6), 547-553. http://dx.doi.org/10.3844/ajassp.2011.547.553 
Holbrook, M. B. (1994). The nature of customer value: An axiology of services in the consumption experience. In Roland T. Rust and Richard L. Oliver, (Eds.), Service Quality: New Directions in Theory and Practice (pp. 21-71). Newbury Park, CA: Sage. http://dx.doi.org/10.4135/9781452229102.n2

Holbrook, M. B. (2000). The millennial consumer in the texts of our times: Experience and entertainment. Journal of Macro marketing, 20(2), 178-192. http://dx.doi.org/10.1177/0276146700202008

Holbrook, M. B., \& Corfman, K. P. (1985). Quality and value in the consumption experience: Phaedrus rides again. In Jacob Jacoby and Jerry C. Olson (Eds.), Perceived Quality: How Consumers View Stores and Merchandise (pp. 31-57). Lexington, MA: Lexington Books.

Holbrook, M. B., \& Hirschman, E. C. (1982). The experiential aspects of consumption: Consumer fantasies, feelings and fun. Journal of Consumer Research, 9, 132-142. http://dx.doi.org/10.1086/208906

Keng, C. J., \& Ting, H. Y. (2009). The acceptance of blogs: using a customer experiential value perspective. Internet Research, 19(5), 479-495. http://dx.doi.org/10.1108/10662240910998850

Keng, C. J., Huand, T. L., Cheng, L. C., \& Hsu, M. K. (2007). Modeling service encounters and customer experiential value in retailing: An empirical investigation of shopping mall customers in Taiwan. International Journal of Service Industry Management, 18(4), 349-67. http://dx.doi.org/10.1108/09564230710778137

Lee, E. J., \& Overby, J. W. (2004). Creating value for online shoppers: Implications for satisfaction and loyalty. Journal of Consumer Satisfaction, Dissatisfaction and Complaining Behavior, 17, 54-67.

Maio, R. G., \& Haddock, G. (2010). The psychology of attitudes and attitude change. SAGE Publication.

Malhotra, N. K. (2004). Marketing research: An applied orientation (4th ed.). New Jersey: Prenticall-Hall.

Malhotra, N. K. (2005). Attitude and affect: new frontiers of research in the 21st century. Journal of Business Research, 58(4), 477-482. http://dx.doi.org/10.1016/S0148-2963(03)00146-2

Mathwick, C., Malhotra, N., \& Rigdon, E. (2001). Experiential value: Conceptualization, measurement and application in the catalog and internet shopping. Journal of Retailing, 77(1), 39-56. http://dx.doi.org/10.1016/S0022-4359(00)00045-2

Morris, S. A., L, N., Gullekson, J, B., Morse, P. M., \& Popovich. (2009). Updating the attitudes toward computer usage scale using American undergraduate students. Computers in Human Behavior, 25(2), 535-543. http://dx.doi.org/10.1016/j.chb.2008.11.008

Nambisan, S., \& Baron, R. A. (2007). Interactions in virtual customer environments: Implications for product support and customer relationship management. Journal of Interactive Marketing, 21(2), 42-62. http://dx.doi.org/10.1002/dir.20077

Park, Y., \& Chen, J. V. (2007). Acceptance and adoption of the innovative use of smartphone. Industrial Management \& Data Systems, 107(9), 1349-1365. http://dx.doi.org/10.1108/02635570710834009

Paterson, L., \& Low, B. (2011). Student attitudes towards mobile library services for smartphones. Library Hi Tech, 22. http://dx.doi.org/10.1108/07378831111174387

Schroeder, H. W. (2012). Giving voice to the experiential value of natural environments. The Humanistic Psychologist, 40(2), 136-152. http://dx.doi.org/10.1080/08873267.2011.642488

Sheth, J. N., Newman, B. I., \& Gross, B. L. (1991). Why we buy what we buy: A theory of consumption values. Journal of Business Research, 22, 159-170. http://dx.doi.org/10.1016/0148-2963(91)90050-8

Solomon, M., Bamossy, G., Askegaard, S., \& Hogg, M. K. (2006). Consumer behaviour: A European perspective (3rd ed.). Pearson Education Limited.

Sweeney, J. C., \& Soutar, G. N. (2001). Consumer perceived value: The development of a multiple item scale. Journal of Retailing, 77(2), 203-220. http://dx.doi.org/10.1016/S0022-4359(01)00041-0

Thaler, R. (1985). Mental accounting and consumer choice. Marketing Science, 4(Summer), 199-214. http://dx.doi.org/10.1287/mksc.4.3.199

Veryzer, R. W. Jr. (1993). Aesthetic response and the influence of design principles on product preferences. Advances in Consumer Research, 20, 224-228.

Wu, C. H. J., \& Liang, R. D. (2009). Effects of experiential value on customer satisfaction with service encounters in luxury-hotel restaurants. International Journal of Hospitality Management, 28(4), 588. 
http://dx.doi.org/10.1016/j.ijhm.2009.03.008

Yadav, M. S., \& Monroe, K. B. (1993). How buyers perceive savings in a bundle price: An examination of a bundle's transaction value. Journal of Marketing Research, 30(August), 350-358. http://dx.doi.org/10.2307/3172886

Zeithaml, V. A. (1988). Consumer perceptions of price, quality, and value: A means-end model and synthesis of evidence. Journal of Marketing, 52(July), 2-22. http://dx.doi.org/10.2307/1251446 